\section{Prof. W. Wardlaw, C.B.E.}

Tre very large number of scientists who knew him personally were grieved to learn of the death of Prof. William Wardlaw on December 19, at the age of sixty-six.

Wardlaw was educated at Neweastle upon Tyne, first at Rutherford College, and then at Armstrong College, in the University of Durham. Although he lived for a large part of his life in the Midlands and in London, he never forgot his connexion with Northumberland and often referred with pride to his early days in the North Country. In 1918 he joined the staff of the Department of Chemistry, University of Birmingham. He proved to be an admirable university teacher and progressed to the rank of senior lecturer in inorganic chemistry. $\mathrm{He}$ was appointed to the chair of physical chemistry in the University of London, tenable at Birkbeck College, in 1937, and he held his professorship for twenty years until his retirement in 1957 , when the title of professor emeritus was conferred on him.

For more than forty years Wardlaw carried out valuable research in inorganic chemistry. During the early stages of his career he investigated some inorganic oxidation processes and made contributions to the chemistry of molybdenum. In the 1930's his interest turned to the stereochemistry of metal complexes. This subject continued to hold his attention for the rest of his life, and by his work he made an important contribution in this field of study. On taking up his appointment in London, Wardlaw had barely succeeded in getting his new department organized when the Second World War began and a halt was called to his research activities. At the conclusion of hostilities he was faced with two major tasks. He had to build up afresh a research group, and to plan and equip a new department, since his College was transferred to new quarter's in Bloomsbury. He attacked both tasks with characteristic vigour. An extensive programme of research on the esters of transition metals was initiated, and under his direction a flourishing research school was developed in the new well-equipped laboratories. The results of this last phase of his research work have had an important influence on the development, of modern ideas of the inter-relation of physical properties with molecular structure.

Wardlaw held strongly the belief that university scientists should not lead an 'ivory tower' existence, and he seized every opportunity to broaden the impact of chemistry upon the community. He sought to widen the range of contacts of scientists in the universities, in industry, and in research associations, and his membership of the Society of Chemical Industry dated from 1917. He was extremely sympathetic towards the difficulties which faced science masters in schools through poor laboratory accommodation, and often spoke up strongly on this point. Scientific publication interested him enormously, and he gave 'considerable thought to the best ways of dealing with the ever-increasing volume of chemical papers. To the professional societies he gave generously of his time and found much pleasure in this service. In later life ho reached high office in these societies, but his many friends testify that his support was equally enthusiastic at the commencement of his career.

During the difficult period $1940-48$, he was honorary secretary of the Chemical Society, and he became president for 1954-56. His first membership of the
Couneil of the Royal Institute of Chemistry dates from 1929 and at the time of his death he was president. To be elected president of both the Chemical Society and the Royal Institute of Chemistry is an honour accorded to few, and is a measure of the esteem in which Wardlaw was held by his professional colleagues and the confidence which his sound judgment inspired.

He had strong sympathy with the aims of the British Association, and the active part he played in its affairs demonstrates his strong conviction that the chemist has responsibilities which extend beyond the boundaries of his profession. In 1952 he presided over the meetings of Section $B$ (Chemistry) and more recently took office as one of the general secretaries. He was closely connected with the current developments in the activities of the Association.

During the Second World War Wardlaw was a joint secretary of the War Cabinet Scientific Advisory Committee, after which he became scientific advisor to the Committee of Appointments in the Ministry of Labour and National Service. Undoubtedly he had a flair for accurate judgment of character and ability, and his advice has been of great national benefit. In 1949 he was created C.B.E.

Wardlaw was always sympathetic to his students and ready to assist in their problems : they responded to his interest with a deep sense of respect and grateful affection. He could not bear slipshod work or laziness, and on occasion his comment and censure could be forthright.

Being a humorous man of much charm, he had a great many friends. His colleagues at Birkbeck College and throughout the University of London always welcomed his company and found joy in his unvarying friendliness. His devoted and wholely selfless service to learning, the public welfare, the advancement of science and the selection and production of scientists, add up to a life-time's work of inestimable value. Scientists, and especially chemists, owe a great deal to Wardlaw, and it is hard to realize that no longer will it be possible to call on his services or to seek his wise counsel.

In 1932 he married Doris Whitfield, who had herself been trained as a chemist, and he never failed to pay tribute to her sympathetic understanding and help in his work. She and their daughter survive hirn.

W. (x. Overend

\section{Prof. A. R. Fulton, M.B.E.}

Angus Robertson Futton, emeritus professor of engineering and drawing in the University of St. Andrews, died at his home in Dundee on November 21.

Born in Dundee on June 23, 1871, he suffered the early misfortune of being left an orphan at the age of five. This affected his opportunities for education, but by courage and determination he acquired $a$ training as an engineer. On qualifying, he worked for some years with Hurst and Nelson, of Motherwell, and it is a testimony to his ability that, although up to that stage he had no university degree, he was invited by Prof. T. Claxton-Fidler to be his assistant in the Engineering Department of University College, Dundee. He spent the rest of his professional life, from 1902 until 1946, on the staff of that Department.

He graduated B.Se. in 1907, and was the main assistant, first, to Prof. Claxton-Fidler, then to his successor, Prof. A. H. Gibson. During the First World War he served for some time in the Royal 